Original Article

\title{
A STUDY ON DRUG-DRUG INTERACTION BETWEEN GLIPIZIDE AND CIMETIDINE IN RABBITS
}

\author{
RANJEETA GHOLVE ${ }^{*}$, DHANESHWAR SHEP ${ }^{2}$, PRAKASHCHANDRA GADE ${ }^{3}$, MANISH RAMAVAT4
}

${ }^{1}$ Department of Science, Maharaja Agrasen School, Memnagar, Ahmedabad, Gujarat, India, ${ }^{2}$ Troikaa Pharmaceuticals Ltd, Commerce House 1, Bodakdev, Ahmedabad, Gujarat, India, ${ }^{3}$ Department of Pharmacology, Dr. Vithalrao Vikhe Patil Foundation's Medical College and Hospital, Ahmednagar, Maharashtra, India, ${ }^{4}$ Department of Physiology, GMERS Medical College, Dharpur, Patan, Gujarat, India ${ }^{*}$ Email: ranjeeta729@gmail.com

Received: 08 Nov 2020, Revised and Accepted: 10 Jan 2021

\section{ABSTRACT}

Objective: To study the effect of Cimetidine ( $\mathrm{H}_{2}$ receptor antagonist) in combination with Glipizide (Sulfonylurea) on the blood sugar level in rabbits.

Methods: Six albino rabbits were taken for the study. Glipizide was administrated to each rabbit as a single drug therapy on day 1 and it was coadministrated with Cimetidine to each rabbit as a combinational drug therapy on day 7. Cimetidine was administrated to each rabbit from day 2 to day 6 as single drug therapy. Blood sugar levels were estimated on day 1 and on day 7 at $0,1,2,4$, and $6 \mathrm{~h}$.

Results: The mean blood sugar level readings at $0,1,2,4$ and $6 \mathrm{~h}$ on day 1 were $90.4,69.4,62.9$ and $65.7 \mathrm{mg} \%$ and on day 7 were $89.4,74.8,65.5$, 56.4 and $61.2 \mathrm{mg} \%$ respectively. When mean blood sugar level on day 1 and day 7 was considered, there was a significant reduction in blood sugar level at 1, 2, 4 and $6 \mathrm{~h}$ and there was no significant fall in blood sugar level at 0 hour after co-administration of Glipizide and Cimetidine.

Conclusion: Cimetidine, when co-administered with Glipizide, significantly increases the hypoglycaemic action of Glipizide.

Keywords: Cimetidine, Glipizide, Hypoglycaemic, Blood sugar

(C) 2021 The Authors. Published by Innovare Academic Sciences Pvt Ltd. This is an open access article under the CC BY license (https://creativecommons.org/licenses/by/4.0/) DOI: https://dx.doi.org/10.22159/ijcpr.2021v13i2.41545. Journal homepage: https://innovareacademics.in/journals/index.php/ijcpr

\section{INTRODUCTION}

Drug-drug interactions may occur when more than one drug is administered in a patient to treat a single ailment or multiple ailments. These concomitantly used drugs may either cause pharmacodynamic or pharmacokinetic types of interactions. The net result of both types of interactions is the alteration in the therapeutic effect of either or both the drugs. There are several diseases that require treatment for a lifetime, e. g., diabetes and hypertension. Patients with such diseases will often need to be administered drugs for treatment of other coexisting diseases, either for a short period or lifelong. There is then a possibility of occurrence of interactions between drugs, resulting in either reduced or enhanced effects of any of the drugs. Therefore, monitoring and readjustment of the dose/s is often necessary to optimize treatment.

In the present study, two diseases (diabetes and gastric ulcers) that may co-exist and require chronic treatment were considered and the occurrence of interaction between the concurrently used drugs was assessed. Diabetes mellitus is a disease characterized by elevated blood glucose levels. It requires treatment for prolonged periods, usually lifelong. Diabetic patients may also have other diseases, e. g., peptic ulcers. In such situations, treatment for the different ailments will have to be given simultaneously. Peptic ulcer is one such disorder that requires treatment for a prolonged period. There are several patients who suffer from both diabetes and peptic ulcers [1]. In such patients, H2-receptor blockers or proton pump inhibitors are administered concomitantly with sulfonylureas or insulin preparations. There are reports that H2-receptor blockers which inhibit the metabolism of sulfonylureas and enhance their bioavailability [1-3].

Cimetidine is well known to interact with a number of drugs concurrently administered by inhibiting hepatic microsomal enzymes [4]. Adverse effects due to the interaction of Cimetidine with Theophylline, Phenytoin, Warfarin [5-7] have been reported. Co-administration of Cimetidine has been found to influence the hypoglycaemic activity of glibenclamide as reported in study conducted in rabbits [8]. Therefore, it is hypothesized that cimetidine (H2-receptor blockers) may also influence the metabolism of glipizide (sulfonylurea). Thus, we thought to evaluate the effect of Cimetidine on hypoglycaemic activity of Glipizide.

\section{MATERIALS AND METHODS}

The study was carried out in the experimental room of the central animal house of Government Medical College, Aurangabad. Six healthy albino rabbits of either sex, weighing between 1.6 and $2.1 \mathrm{~kg}$ were used in the study. The study was approved by Institutional Animal Ethics Committee, Government Medical College, Aurangabad. After getting approval from Institutional Animal Ethics Committee, the study was conducted under the guidelines of the Committee for the Purpose of Control and Supervision of Experiments on Animals (CPCSEA).

Rabbits were kept for fasting overnight for $18 \mathrm{~h}$. Water was given at libitum and rabbits were kept at temp between $30-33^{\circ} \mathrm{C}$. For oral feeding rabbits, a special rabbit holding box and mouth gag with feeding tube was used. During $7 \mathrm{~d}$ of the study period, each rabbit was given Glipizide and Cimetidine as single-drug therapy and also as combination therapy as shown below.

Day 1: Glipizide

Day 2-6: Cimetidine

Day 7: Glipizide+Cimetidine

All the drugs were suspended in $2 \%$ gum acacia and then administered. Doses of all the drugs were calculated from Fundamentals of experimental pharmacology by Ghosh [9]. About 1 $\mathrm{ml}$ of blood was collected from marginal ear vein of the rabbits for blood glucose estimation on day 1 and on day 7 at $0,1,2,4$, and $6 \mathrm{~h}$. Blood sugar levels were estimated by modified Somogy's method and expressed as milligram per $100 \mathrm{ml}(\mathrm{mg} \%)$.

\section{Statistical analysis}

Mean blood sugar levels were expressed as milligram per 100 $\mathrm{ml} \pm$ Standard Deviation ( $\mathrm{mg} \% \pm \mathrm{SD}$ ). The Student's t-test was used to test the significance of the difference between treated groups for the 
blood sugar level on day 1 and day 7 at $0,1,2,4$ and $6 \mathrm{~h}$ in each treated group and taken as significant at $\mathrm{p}<0.05$.

\section{RESULTS}

The mean blood sugar level readings at $0,1,2,4$ and $6 \mathrm{~h}$ on day 1 were $90.4,69.4,62.9$ and $65.7 \mathrm{mg} \%$ and on day 7 were 89.4, 74.8,
65.5, 56.4 and $61.2 \mathrm{mg} \%$ after administration of Glipizide+Cimetidine respectively. When mean blood sugar level on day 1 and day 7 were considered, there was a significant reduction in blood sugar level at 1, 2, 4 and $6 \mathrm{~h}$ and there was no significant fall in blood sugar level at 0 hour after co-administration of Glipizide and Cimetidine.

Table 1: Effect of cimetidine on hypoglycaemic activity of glipizide in rabbits

\begin{tabular}{|c|c|c|c|c|c|}
\hline \multirow[t]{2}{*}{ Drug } & \multicolumn{5}{|c|}{ Mean blood sugar level (mg \% \pm SD) $(n=6)$} \\
\hline & $\mathbf{O} \mathbf{h}$ & $1 \mathrm{~h}$ & $2 \mathrm{~h}$ & $4 \mathrm{~h}$ & $6 \mathrm{~h}$ \\
\hline Glipizide (Day 1) & $90.4 \pm 1.41$ & $78.1 \pm 1.54$ & $69.4 \pm 1.14$ & $62.9 \pm 2.35$ & $65.7 \pm 2.51$ \\
\hline Glipizide+Cimetidine (Day 7) & $89.4 \pm 1.47$ & $74.8 \pm 1.45$ & $65.5 \pm 1.65$ & $56.4 \pm 0.99$ & $61.2 \pm 2.27$ \\
\hline P-value & $>0.05$ & $<0.01$ & $<0.001$ & $<0.0001$ & $<0.01$ \\
\hline
\end{tabular}

Values were expressed in mean \pm SD, Significant at $\mathrm{P}<0.05$

\section{DISCUSSION}

Cimetidine is a potent inhibitor of liver microsomal activity, which may also decrease hepatic blood flow. Although a multitude of interactions with cimetidine has been evaluated, many of these are incompletely described or understood. Some studies have revealed the existence of number of drug interactions involving the inhibition of hepatic microsomal drug metabolism by drugs containing aromatic nitrogenous basis such as imidazole structure [4].

According to a study conducted by Feely et al., the administration of $\mathrm{H} 2$ antagonists produces a marked reduction in blood sugar level in diabetic patients receiving glipizide and suggested the possible cause as the inhibition of glipizide metabolism by $\mathrm{H} 2$ antagonist [10]. As glipizide is completely absorbed and metabolized extensively in the liver [11] it is possible that a decrease in blood sugar level may be due the increased glipizide concentrations, which may be due to effect of cimetidine on hepatic metabolism.

As sulphonylureas are well known to be metabolized by liver microsomal enzyme system [11], the decrease in blood sugar level in combination with sulphonylureas is possible due to an effect of $\mathrm{H} 2$ receptor antagonist on hepatic metabolism.

Cimetidine an imidazole derivative has high binding affinity for cytochrome P450 enzymes [12] and thus decreases the hepatic microsomal drug metabolism which is responsible for prolong action of the drug co-administered along with cimetidine. The effects of cimetidine on hepatic metabolism are well recognised and on the same basis it is well known to interact with number of drugs like warfarin [7], Phenytoin [6], Theophylline [5] propranolol [13] lignocaine [14].

In the present study at 0 hour, there was no significant change in blood sugar level which clearly indicates that cimetidine by itself exerts no effect on blood sugar level or they do not have hypoglycaemic activity.

\section{CONCLUSION}

Cimetidine, when co-administered with Glipizide, significantly enhances hypoglycaemic action of Glipizide. Therefore, coadministration of Glipizide with Cimetidine needs to be carefully monitored in diabetic patients, as glucose control may be affected due to drug-drug interaction.

\section{ACKNOWLEDGMENT}

The authors are grateful to Government Medical College, Aurangabad and Pharmacology Department staff for their cooperation throughout this study.

\section{FUNDING}

\section{AUTHORS CONTRIBUTIONS}

All the authors have contributed equally.

\section{CONFLICTS OF INTERESTS}

The authors declare that they have no conflicts of interest.

\section{REFERENCES}

1. VKM Swamy, RS Setty, MM Shankaraiah, TM Jyothi, SV Rajendra. A study on drug-drug interaction of esomeprazole and anti-diabetic drugs. J Young Pharm 2010;2:424-7.

2. Kubacka KJ, Antal AL, Juhl RP. Paradoxical effects of cimetidine and ranitidine on glibenclamide pharmacokinetics and pharmacodynamics. Br J Clin Pharmacol 1987;23:743-51.

3. Davis SN, Granner DK. Insulin, oral hypoglycaemic agents and pharmacology of endocrine pancreas. In: Hardman JG, Limbird LE, Gilman AG. editors. Goodman and Gilman's the pharmacological basis of therapeutics. 9th ed. NewYork: Megraw-Hill; 1996. p. 901-15.

4. Lin JH, Chremos AN, Chiou R, Yeh KG, William R. Comparative effect of ranitidine and cimetidine on pharmacokinetics of theophylline in normal volunteers. BJCP 1987;24:669-72.

5. Vestel RF, Thummel KE, Murrer B. Cimetidine inhibit theophylline clearance in COPD. BJCP 1983;15:411-8.

6. Hetzel DJ, Bochner F, Hallpike JF, Shearman DJC, Hann CS. Cimetidine interaction with phenytoin. $\mathrm{Br}$ Med J 1981;282:1512

7. Hetzel DJ, Binkette D, Miners J. Cimetidine interaction with warfarin. Lancet 1979;314:317-9.

8. Dhaneshwar Shep, Rohan S Phatak, Narendersingh Sidhu, Prakashchandra Gade. Comparative effects of cimetidine on hypoglycaemic activity of glibenclamide in rabbits. Pravara Med Rev 2019;11:5-8.

9. Ghosh. Fundamental of experimental pharmacology. Edition-II; 2008. p. 154-5.

10. Feely JW, Collins WCJ, Cullen M, Pedden NP. Potentiation of the hypoglycaemic response to glipizide in diabetic patients by $\mathrm{H} 2$ receptor antagonist. BJCP 1993;35:321-3.

11. Melander A, Bitzen PO, Faber O, Groop L. Sulphonylurea antidiabetic drugs. Drugs 1989;37:58-72.

12. Knodell RG, Holtzman JL, Crankshaw DL, Stede NM, Stanley LN. Drug metabolism by rat and human hepatic microsomes in response to interaction with $\mathrm{H} 2$ receptor antagonists. Gasteroentrology 1982;82:84-8.

13. Heagerty AM, Donovan MA, Patel L. The influence of $\mathrm{H} 2$ receptor antagonist on propranolol pharmacokinetics. Int J Clin Pharm Pes 1982;2:203-5.

14. Feely J Wilkinson GB, Mc Allister CB. Increased toxicity and reduced clearance of lidocaine by cimetidine. Ann Intern Med 1982;96:592-4 